Volume 7 Issue 1, March 2020

Nationally Accredited Journal,

Decree No. B/4130/E5/E5.2.1/2019

\title{
Notary Role In The Process Of Establishment Of Foreign Investment Company Limited Statutory Company Limited In The City Kendari
}

\author{
Bayu Dewa Lumanga ${ }^{1}$ and Amin Purnawan ${ }^{2}$
}

Abstract. The purpose of this research are: 1) To analyzing role notary in the process of establishment of foreign investment limited liability company under the laws of a limited liability company in Kendari. 2) To analyzing obstacles is facing a notary in the process of establishment of the Foreign Investment Limited Liability Company under the laws of a limited liability company in Kendari and provide solutions to these obstacles. The method used by researchers is empirical approach juridical law and specification in this study were included descriptive analysis. As for sources and types of data in this study are primary data obtained from field studies with interview Notary in Kendari. And secondary data obtained from the results of research studies that literature. Based on The role of the Notary In Process Incorporation Limited Liability Investment Asing based on Act of Company Limited in Kendari is providing legal advice and pouring the will of the parties to the deed of incorporation in order to not conflict with existing regulations and is responsible for ensuring the deed of incorporation approved by the Minister of Justice and Rights Human Rights of the Republic of Indonesia, and once approved, the deed of establishment is the highest law for limited liability companies and limited liability company and a binding third party. Barriers Faced Notary In Process Incorporation Limited Liability Based on the Foreign Investment Limited Liability Company Act in Kendari is: a) Business Licensing; b) domicile Enterprises; c) Determination Business Sector; d) Administrative requirements; e) Capital To Establish Company. The solution is: a) It helps if you first understand your business; b) In selecting the business domicile you should use the designation of the building is for the business; c) In such case, please see the business field closest correlation with the idea; d) In person at the local PTSP to determine the current terms to provide a solution establishing businesses; e) Learn first line of business you will run.

Keywords: Role; Notary; Incorporation; Limited Liability Company (PT); Foreign Direct Investment (FDI)

\section{Introduction}

From Regulation Notary and Law Notary above it can be concluded that the principal task of the notary is to make the deeds authentic, where the authentic act pursuant to Article 1870 BW (Burgelijk wetboek) provide to the parties who made an agreement that absolute, Therein lies the importance of the profession of notary, the notary is authorized to create a tool that is absolute proof by law, in the sense that what is mentioned in an authentic deed was essentially considered correct. It is very important for those who need a verification tool for a purpose, either for personal benefit or for the benefit of an undertaking that activity in the business field. ${ }^{3}$

\footnotetext{
${ }^{1}$ Student Mastrr of Notary Program Faculty of Law, Sultan Agung Islamic University Semarang, email e-mail: bayuedware@gmail.com

${ }^{2}$ Lecturer of Faculty of Law, Sultan Agung Islamic University Semarang

3 R. Soegando Notodisoejo, 1982, Hukum Notariat Di Indonesia Suatu Penjelasan, Rajawali, Jakarta, p 8
} 
Limited Liability Company (PT) is the establishment of economic activities most preferred at this time, because in addition to the accountability that is limited, Limited Liability Company also makes it easy for owners (shareholders) to divert the company (to everyone) to sell the entire share holding in the company, as well as other benefits. $^{4}$

Indonesia itself has a Limited Liability Company Law (Company Law) No. 1 of 1995, which contains a complex of matters relating to the provisions of the Limited Liability when compared with the provisions contained in the Book of the Law of Commercial Law (Commercial code) is born first and is a product of Dutch colonial heritage law.

The role of the notary in the era of free trade in deed a limited liability company, particularly in terms of Foreign Direct Investment (FDI), are very important and are required to master a variety of disciplines, not just discipline notaries. This is because the notary is now faced with a complex problem, both as a result of economic development, political, social and cultural community as well as changes in laws and legislation. Today, with the opening of the business world in Indonesia for investment from domestic investors and foreign investors to invest in Indonesia, it will provide a considerable impact on the company that is mainly limited liability companies, including the role of the notary in carrying out the job of making akta- authentic act for the benefit of investors,

Of some forms of enterprise that exist in Indonesia, ${ }^{5}$ limited liability company is the most popular form of companies in the business and most widely used by the business/ investor in carrying out business activities in various fields. In addition to having a clear legal basis as stipulated in Law No. 2007 on Limited Liability Company 40Tahun $^{6}$, A limited liability company (PT) is also felt over the safety of the shareholders / owners of capital in the attempt. Running a business with container PT has some obvious advantages, namely the existence of limited liability for shareholders. Shareholder is only responsible for a number of nominal value of shares he owned. In addition there are three (3) the dominant characteristic that PT is a form appropriate effort used in the development capital and is a major orientation of any businessperson or investor, namely: ${ }^{7}$

- liability arising solely charged to the assets pooled in associations;

- mobility nature of the right to participation;

- the principle of maintenance through an organ.

The deed of establishment of PT, including for PT PMA, must be stated in the deed made before a notary, includes changes to statutes and company data changes should be made in the presence of or by a notary, ${ }^{9}$ because the notary deed serves also as a

\footnotetext{
${ }^{4}$ Ahmad Yani and Gunawan Widjaja, 2003, Perseroan Terbatas, King Grafindo Persada, Jakarta, p. 1

${ }^{5}$ Companies can be divided into several categories: A. Judging from its capital origin: (i) in the country (DCI) is the national state enterprises and the private sector; (Ii) foreign (FDI) and foreign (mixed). B. Judging from the absence of legal entities: (i) form a legal entity such as Cooperative, Public Corporation (Perum-SOE) and Company Limited; (Ii) that the company is not a legal entity such as the Civil Alliance, Firm and CV (Commanditer Venotschap). Handri Raharjo, cast. 1, (Yogyakarta: Pustaka Yustisia, 2009), p. 4-5.

${ }^{6}$ Indonesia (A), the Limited Liability Company Act, Act No. 40 of 2007, LN No. 106 of 2007, Supplement No. 4756

7 Salim HS and Budi Sutrisno, 2008, Hukum Investasi di Indonesia, ed. 1-2, cet. 1, Jakarta: Rajawali Press, p. 171.

${ }^{8}$ Indonesia (A), op. cit., Art. 7 paragraph (1)

${ }^{9}$ Ibid, Ps. 21 paragraph (5)
} 
Volume 7 Issue 1, March 2020

Nationally Accredited Journal,

Decree No. B/4130/E5/E5.2.1/2019

medium to get the endorsement of the establishment, approval and the receipt of notification on amendment and change of data from the company and to the Minister of Justice and Human Rights. In addition it was determined that the notary as the power of the Board of Directors of applying for endorsement, approval and notification. ${ }^{10}$ Therefore the role of the notary in the manufacture of the deed of PT to be very important, as ordered by the regulations.

Based on the above problems, the purpose of this study as follows: To analyzing role notary in the process of establishment of foreign investment limited liability company under the laws of a limited liability company in Kendari; and To analyze barriers have you encountered a notary in the process of establishment of Foreign Investment Limited Liability Company under the laws of a limited liability company in Kendari and provide solutions to these obstacles.

\section{Research methods}

The method used in this research is the empirical study. Specification juridical approach used in this study was descriptive, ${ }^{11}$ as explained, describe or disclose the legislation in force associated with the theories of law and positive law enforcement practice concerning these issues. This study provides an overview of the role of the Notary In the process of establishment of limited liability company (PT) Foreign Direct Investment (FDI). As for sources and types of data in this study are primary data obtained from field studies with interview Notary in Kendari. And secondary data obtained from the study of literature.

\section{Results and Discussion}

\subsection{Notary Role In The Process Incorporation Foreign Investment Company Limited Under the Corporate Law in Kendari}

Based on the explanation of the Law of the Republic of Indonesia Number 40 Year 2007 on Limited Liability The national economy organized based on economic democracy with the principles of togetherness, efficiency with justice, sustainability, environmental friendliness, independence, and balancing progress and national economic unity aims to realize welfare society. Enhancement national economic development needs to be supported by a Acts governing limited liability company that can ensure a conducive business climate.

During this limited liability company has been set up by Act No. 1 of 1995 on Limited Liability Company, which supersedes the legislation derived from the colonial era. However, in its development provisions in the legislation is deemed no longer meets the legal developments and needs of the community because of the economy and the advancement of science, technology, and information has grown so rapidly, especially in the era of globalization. In addition, increasing public guidance be fast, rule of law,

\footnotetext{
${ }^{10}$ Ministry of Justice and Human Rights of the Republic of Indonesia, Validation Application Procedures Law Firm, Approval of Amendment of Articles of Association, Submission of Notifications such Amendment and Change Data Company, Ministry of Justice and Human Rights of the Republic of Indonesia Number: M.HH02.AH.01.01 In 2009, BN No. 17 In 2009, Ps. 2 paragraph (1), Ps. 9, Ps. 13 paragraph (1) and Ps. 14 paragraph (1).

${ }^{11}$ S. Margono, 2003, Metodologi Penelitian Pendidikan, Rineka Cipta, Jakarta, p. 37
} 
which demands the development of the business in accordance with the principles of good corporate governance (GCG) demanded improvement of Act No. 1 of 1995 on Limited Liability Company.

With regard to the request for ratification of a legal entity of the Company, stated that the appeal is the authority of the founders together that can be implemented alone or authorized to notary. Acta of Association which was approved and the deed of amendment to statutes that have been approved and / or notified to the Minister recorded in the list the Company and published in the Official Gazette of the Republic of Indonesia by the Minister. In the case of a legal entity status, approvals and / or receipt of notification of changes in the constitution, and other data changes, the Act This law is not linked to the law on compulsory registration of the Company. To further clarify and reinforce the provisions concerning Organ Company, in this legislation to amend the provisions concerning the Annual General Meeting of Shareholders (AGM) to take advantage of developments technology. Thus, the holding of the AGM can be done through electronic media such as teleconferencing, video conferencing, or other means other electronic media.

Based on Law No. 40 Year 2007 on Limited Liability under Article 7:

(1) The Company was founded by two (2) or more persons under deed made in Indonesian.

(2) Each of the founders of the Company shall take shares when the Company was founded.

(3) The provisions referred to in paragraph (2) shall not apply in the context of smelting.

(4) The Company obtain legal status on the date of issuance of a ministerial decree on ratification of the legal entity of the Company.

(5) After the Company obtain legal status and shareholders to less than 2 (two), within a maximum period of 6 (six) months from the situation of shareholders concerned shall transfer part of its shares to another person or company issuing new shares to the other.

(6) In the event that the period referred to in paragraph (5) has been exceeded, the shareholders remain less than 2 (two), shareholders are personally liable for any engagement and losses of the Company, and at the request of the parties of interest, the district court may dissolve the Company's bank ,

(7) The provisions require the Company was founded by two (2) or more persons referred to in paragraph (1), and the provisions of paragraph (5), and subsection (6) does not apply to:

a. Limited which is wholly owned by country; or

b. Company that manages the stock exchanges, clearinghouses and underwriting, settlement and depository institutions, and other agencies as stipulated in the law on the capital market.

Article 8

(1) The deed of establishment including articles of association and information la in relating to the establishment of the Company.

(2) Other information referred to in paragraph (1) contain at - least:

a. full name, place and date of birth, occupation, residence, and citizenship founder of individuals, or the name, domicile and address details as well as the number and date of the minister's decision regarding ratification of legal entities of the founders of the Company;

b. full name, place and date of birth, occupation, residence, nationality of the Directors and the Board of Commissioners for the first time in the lift; 
Volume 7 Issue 1, March 2020

Nationally Accredited Journal,

Decree No. B/4130/E5/E5.2.1/2019

c. The names of shareholders who have taken part in shares, details of the number of shares and par value of shares issued and outstanding.

(3) In making the certificate of incorporation, the founders may be represented by another person by power of attorney.

Based on interviews with the notary Mr Sudirman, SH., M.Kn in Kendari ${ }^{12}$ that the role of the Notary in Process Incorporation Limited Liability Foreign Investment Under Law Limited Liability Company in the City Kendari is give out legal advice and pouring the will of the parties to the deed of incorporation in order to not conflict with existing regulations and is responsible for ensuring the deed of incorporation approved by the Minister of Justice and Rights Human Rights of the Republic of Indonesia, and once approved, the deed of establishment is the highest law for limited liability companies and limited liability company and a binding third party. Rule applies if it is not stipulated in the deed of establishment. Not all terms of the agreement of the parties made before the Joint Venture Agreement or other agreements set forth in the Deed of Establishment,

\subsection{Barriers Faced Notary In Process Incorporation Limited Liability Based on the Foreign Investment Limited Liability Company Act in Kendari and the solution}

PT Foreign Direct Investment (FDI) is a limited liability company incorporated under the laws of Indonesia. Regarding foreign investment itself, the Investment Law defines it as an investing activity to do business in the territory of the Republic of Indonesia, made by a foreign investor, whether using foreign capital and joint venture with a domestic investor. Although both categorized as a limited liability company, PT PMA has differences with PT in general. In the PMA, both foreign citizens or foreign legal entity can establish PMA in Indonesia. However, in some aspects of the business is run, PMA still in need of Indonesian Citizens and Legal Entities Indonesia to be able to run his effort. Instance, For foreign investors who want to invest in Indonesia, the first such investor's home country has made agreements Bilateral Investment Treaties (BITS) with Indonesia. This agreement is an agreement made between the two countries concerning investment activities. BITS also contains rules between the two countries on how investments direct investments made by nationals of one country in another country can be protected. Usually the agreement is made by the state investor and recipient countries capital. Theoretically, this agreement includes protection of investment flows in both directions, but in practice only applies in one direction only, ie flow of investment from investors to the capital recipient country. ${ }^{13}$

Foreign Investment Company Limited (PT.PMA) is a business entity with legal status by using legal mechanisms in Indonesia, most or all of the capital of these enterprises are owned by foreigners / coming from other countries. This provision means, one of the founders of the founders of the limited liability company is a person who comes from another country and paid-up capital purely from their own country.

The establishment of PT. PMA is one of the conditions set out in legislation investment for foreigners to be able to invest directly in Indonesia. In general requirement to

\footnotetext{
12 Results of interviews with Mr. Sudirman, SH., M.Kn as a Notary Public in Kendari, on December 17, 2019, 13:15 pm

${ }^{13}$ Siti Anisah \& Lucky Suryo Wicaksono, 2017, Hukum Investasi, FH UII Press, Yogyakarta, p. 94.
} 
establish PT. PMA is the same with the establishment of PT. Domestic investment, the difference is only an element of equity ownership in the company. PT. Overall domestic capital owned by Indonesian citizens, while PT. PMA partly or wholly owned by foreigners.

According to M. Yahya Harahap ${ }^{14}$ morking basis of the entire nominal value of shares of the Company named in the Articles of Association. The authorized capital of the Company in principle, is the total number of shares that may be issued by the Basic company. The budget that determine how the number of shares used as the basic capital. The amount specified in the Articles of Association is "purely nominal value, Article 32 of Law Number 40 Year 2007 regarding Limited Liability Company ("Company Law") set as follows:

(1) The authorized capital of the Company at least Rp50,000,000.00 (fifty million rupiah).

(2) Act to regulate certain business activities can determine the minimum amount of capital that is greater than the Company's authorized capital provisions referred to in paragraph (1).

(3) Changes in basic capital amount referred to in paragraph (1) shall be stipulated by Government Regulation.

Based on an interview with Mr. Sudirman, SH., M.Kn in Kendari ${ }^{15}$ Notary of the obstacles faced in the process of establishment of the Foreign Investment Limited Liability Company based Limited Liability Company Act in Kendari such as:

- Business Licensing

- domicile Effort

- Determination Business fields

- Administrative Requirements

- Capital To Establish Company

Solutions to overcome resistance Notary encountered in the process of establishment of the Foreign Investment Limited Liability Company based Limited Liability Company Act in Kendari among which:

- It helps if you first understand your business. If your business is something new, you need to recognize the character of the business in order to identify the type of license you need.

- In choosing a business domicile you should use the designation of the building is for the business. This designation types you can see in the document IMB (Building Permit) from the building. Indeed, in some areas are still allowed to use the residence as a business domicile, but chose a building with the designation IMB place of business would be anticipatory measures for the sustainability of your company.

- In such case, please see the business field closest correlation with the idea. Ensure that all core business which will run listed in the deed of establishment of PT.

- Come directly to the local PTSP to determine the current terms to provide a solution establishing businesses. Ensure that all documents such as ID cards and TIN formats in accordance with the requirements.

- Learn first line of business you will run. Determine if there are minimum capital requirements for operations in the field. If there is no minimum capital requirement, you can use the provisions of the minimum authorized capital in the Company Law.

\footnotetext{
${ }^{14}$ M.Yahya Harahap, 2009, Hukum Perseroan Terbatas, Sinar Grafika, Jakarta, p. 233

15 According to interviews with Mr. Sudirman, SH., M.Kn as a Notary Public in Kendari, on December 17, 2019, 13:15 pm
} 
Volume 7 Issue 1, March 2020

Nationally Accredited Journal,

Decree No. B/4130/E5/E5.2.1/2019

\section{Closing}

\subsection{Conclusion}

Based on the description and thought in the discussion above, we can conclude several things:

- Notary Role In The Process Incorporation Foreign Investment Company Limited Under the Corporate Law in Kendari

Providing legal advice and pouring the will of the parties to the deed of incorporation in order to not conflict with existing regulations and is responsible for ensuring the deed of incorporation approved by the Minister of Justice and Human Rights of the Republic of Indonesia, and once approved, the deed of establishment is the highest law for limited liability companies and bind a limited liability company and a third party. Rule applies if it is not stipulated in the deed of establishment. Not all terms of the agreement of the parties made before the Joint Venture Agreement or other agreements set forth in the Deed of Establishment, therefore JVA expressly limited liability company can be declared binding by the General Meeting of Shareholders, to the extent not contrary to the regulations and the deed of establishment is not set

- Barriers Faced Notary In Process Incorporation Limited Liability Based on the Foreign Investment Limited Liability Company Act in Kendari and the solution

Resistance: Business Licensing; domicile Effort; Determination Business fields; Administrative Requirements; Capital To Establish Company

Solution:

- It helps if you first understand your business.

- In choosing a business domicile you should use the designation of the building is for the business.

- In such case, please see the business field closest correlation with the idea. Ensure that all core business which will run listed in the deed of establishment of PT.

- Come directly to the local PTSP to determine the current terms to provide a solution establishing businesses.

- Learn first line of business you will run. Determine if there are minimum capital requirements for operations in the field. If there is no minimum capital requirement, you can use the provisions of the minimum authorized capital in the Company Law.

\subsection{Suggestion}

- In the establishment of PT in accordance with Article 7 (1) of the Act. NO. 40 Year 2007 regarding Limited Liability Company, the parties must establish PT Deed, because the notarial deed of establishment of PT is the authentic evidence of the establishment of a limited liability company and is a requirement to obtain authorization from the Minister of Law and Human Rights. And in deed only make suitable notary authorized by Article 1 (1) of the Act. No. 30 of 2004 concerning Notary office.

- Communities that want to establish a Limited Liability Company (PT) Foreign Direct Investment (FDI) is expected to know more about the conditions and processes of 
the establishment of PT PMA, so as to save time and simplify the Notary in the establishment of PMA.

\section{References}

[1] Ahmad Yani and Gunawan Widjaja, 2003, Perseroan Terbatas, King Grafindo Persada, Jakarta

[2] GHS Lumban Tobing, 1991, Pengaturan Jabatan Notaris, Erland, Jakarta

[3] Gunawan widjaja 2008, 150 Tanya Jawab Tentang Perseroan Terbatas, Forum Friend, Jakarta

[4] HMN Purwosutjipto, 1979, Pengertian Pokok Hukum Dagang Indonesia, Djambatan, Jakarta

[5] Habibi Ajdie, 2008, Hukum Notaris Indonesia (Tasir Tematik Terhadap UU No. 30 Tahun 2004 Tentang Jabatan Notaris), reflika Aditama, Bandung

[6] Indonesia (A), the Limited Liability Company Law, Law No. 40 of 2007, LN No. 106 of 2007, Supplement No. 4756

[7] M.Yahya Harahap, 2009, Hukum Perseroan Terbatas, Sinar Grafika, Jakarta

[8] Muhammad Nazir, 1988, Metode Penelitian, Ghalia Indonesia, Jakarta

[9] Muhammad Yamin, 1982, Proklamasi dan Konstitusi Republik Indonseia, Ghalia Indonesia, Jakarta

[10] O. Notohamidjojo, 1970, Makna Negara Hukum, Badan Penerbit Kristen, Jakarta

[11] Padmo Wahyono, 1984, Guru Pinandita, Agency Publisher University of Indonesia, Jakarta

[12] Companies can be divided into several categories: A. Judging from its capital origin: (i) in the country (DCI) is the national state enterprises and the private sector; (Ii) foreign (FDI) and foreign (mixed). B. Judging from the absence of legal entities: (i) form a legal entity such as Cooperative, Public Corporation (Perum-SOE) and Company Limited; (Ii) that the company is not a legal entity such as the Civil Alliance, Firm and CV (Commanditer Venotschap). Handri Raharjo, Hukum Perusahaan, cet. 1, (Yogyakarta: Pustaka Yustisia, 2009)

[13] R. Soegando Notodisoejo, 1982, Hukum Notariat Di Indonesia Suatu Penjelasan, Rajawali, Jakarta

[14] S. Margono, 2003, Metodologi Penelitian Pendidikan, Rineka Cipta, Jakarta

[15] Salim HS and Budi Sutrisno, 2008, Hukum Investasi di Indonesia, ed. 1-2, cet. 1, Jakarta: Rajawali Press

[16] Siti Anisah \& Lucky Suryo Wicaksono, 2017, Hukum Investasi, FH UII Press, Yogyakarta 